\title{
Open Innovation in Service Industry
}

\author{
Lalu M. Furkan* \\ Management \\ University of Mataram \\ Mataram, Indonesia \\ lalu.furkan@unram.ac.id \\ Luluk Fadliyanti \\ Management \\ University of Mataram \\ Mataram, Indonesia \\ fadliyanti@gmail.com
}

\author{
A Agusdin \\ Management \\ University of Mataram \\ Mataram, Indonesia \\ dragusdin@gmail.com \\ Imanuella R.A \\ Management \\ University of Mataram \\ Mataram, Indonesia \\ imanuelita@gmail.com
}

\author{
Embun Suryani \\ Management \\ University of Mataram \\ Mataram, Indonesia \\ embunsur74@gmail.com

M Muhdin
Management
University of Mataram
Mataram, Indonesia
muhdin@unram.ac.id

\begin{abstract}
Service industry is an emerging industry which contributing a significant trend of contribution to GDP in developed countries. Tourism industry plays a vital role on the Indonesia economy where tourism corridor strategy located in Bali, West Nusa Tenggara, and East Nusa Tenggara. Technological changes might shape the tourism industry in many different ways. The sustainable tourism village industry development has become a topical agenda of development in Indonesia. This study explores to what extent the Lombok sustainable tourism village industry development has engaged open innovation practices. The Setanggor tourism village, Mertak tourism village, and Pijot tourism village were elected on the case study. Focus group discussion with stakeholders employed on this study and it was followed by in-depth interview with key informants during study period between January 2018 and October 2020. The finding explores inbound open innovation and outbound open innovation among the Lombok sustainable tourism village. Further networks and actors involved were also described in great detail on the paper.
\end{abstract}

Keywords-- Service industry, tourism industry, the sustainable tourism village industry, cluster, open innovation

\section{INTRODUCTION}

Service industry shows a significant contribution to the global economy where tourism is one of the contributors. A shifting trend from manufacture to service industry has driven innovation dynamics on service industry sector. Open innovation terminology for the first time was mentioned by Henry Chesbrough [1] when he published his book "The New Imperative for creating and profiting from technology. He highlighted the importance of closed innovation in the early $20^{\text {th }}$ century. Most companies provided R\&D budget and recruited the best engineer on the regions for research and development activities to meet customer needs and finally enjoy much profit. This innovation strategy could not be used any longer since the radical changes on the industry when internet introduced for the first time at the entrance year of 2000. This helped companies for knowledge and technology exchanges for free and they might extend the network and maintain their competitiveness globally [1]. Open innovation has taken much attention from industry and academics to the importance of inflowing knowledge and technology to companies and use it to expand the market as part of internal and external innovation [3,4]. It has been researched on various industry in many countries to explain open innovation, innovation process, and deeper understanding on its benefits on great detail [2, 4, 5, 6, 7, 8, 9]. However, most open innovation research has focused on the multinational corporation and only few researches highlighted on small-and-medium-sized enterprises which is still fragmented [10, 11, 7]. Although, recent studies have focused on open innovation in small-and-medium-sized enterprises in many contexts with different complexities, so that, there is a critical challenge to measure the level of openness innovation $[12,11]$. This might confuse scholars to explain open innovation in great detail to all aspects.

Aim of this research is to explore to what extent the Indonesian tourist village industry have practiced open innovation. This research might contribute deeper understanding of the level of openness innovation in smalland- medium-sized enterprises on the Indonesia context.

\section{METHODS}

\section{A. Research Setting}

The research setting was in the Lombok tourist village industrial cluster. The Lombok Setanggor tourist village, the Mertak tourist village, and the Pijot tourist village were selected because of some reasons. First, The tourist village industrial cluster development is a national program to support the achievement of 20.000 .000 international visitors in 2019 [13]. Second, The Lombok tourist village industrial cluster development is to support the Mandalika special region economic development. Third, Socio-economic tourism development should be developed by the tourist village industrial cluster development, therefore, it searches for the best practice model of the tourist village industry

\section{B. Research Design}

Given the earlier works of open innovation model by Van de vrande et al [7], we applied an exploratory case study research strategy with qualitative methods $[14,15]$. This method helps us to explore the service innovation on the Lombok tourist village industrial cluster as well as to identify the emerging concept $[14,15,16]$. We follow replication logic to select the case study, employing an analytic induction approach to explain the phenomena observed by stipulating a set of causal linkage among the research constructs [15]. Initially, induction approach introduced by Znaniecki [17] for the best development logic 
for theory development and testing across case studies [18]. This method generates hypothesis or propositions from the first case study. Thus from the first hypotheses inform the data collection from the second case. Each hypotheses were compared to the data collected on the other cases, and if necessary reformulating hypotheses to take account from the first case. There are two selected tourist village industrial cluster as a target for the construction of this study. We selected the tourist village based on the following criteria: 1) They have been in operation for tourism village development 2) They have been acknowledging by the national and local government and also support the tourism village development on the case studies. They should involve community-based tourism for the tourist village development. Therefore, the selected cases were representative sample since not all tourist village industrial clusters have been operationalized and profitable and meet requirement above. Further, it also offered variations in the constructs being investigated $[19,20,21]$.

\section{Data Collection}

This study depends on the three primary data sources: archives, in-depth interview, and focus group discussion. Indepth interviews were conducted among the internal and external informants to obtain general perspective about open innovation on the selected case studies. We had in-depth interview with our informants starting from ideas generation to industrialization, government and other institutions support and recommendation. We also had interviews with tourism experts to obtain brief understanding regarding the tourist village industrial cluster. This information was also supported with wide range of archives and focus group discussion, internal documents, websites and other secondary data analysis. We collected the data from 2018 and 2020. The first interviews took place on April 2018 and followed by in-depth interview and focus group discussion.

\section{Data Analysis}

In our case studies, we emphasized on similarities and differences when comparing the three case studies to identify emerging patterns and themes [14]. Graph and tables were used to map out and compare several possible constructs at once [22]. From the emerging constructs and themes, we obtained relationship views between construct and contingency (Eisenhardt, 1989) [16]. Multiple case study allows several levels of analysis using the interviews, focus group discussion, archives data and observation [20]. Our study applied the framework Van de vrande et al [7] for further discussion about open innovation. We clarified: 1) to what extent the Lombok tourist village industrial cluster have engaged open innovation activities. 2) Clarified actors involved on the Lombok tourist village industrial cluster. 3) Identified the formation of the Lombok tourist village industrial cluster in producing the open innovation practices.

\section{RESULT AND DISCUSSION}

\section{A. Result}

\section{The Indonesian Tourist Village Industry}

The Indonesian government have given the mandate to the three provinces: Bali, West Nusa Tenggara, and East
Nusa Tenggara for the tourism development corridor. These areas have become the leading sector for the tourism industry growth. Tourist village industry development program is one of the ministries of tourism agenda to boost domestic and international visitors in Indonesia. It offers socio and culture life binding to natural village views and local values. Each village have different uniqueness to satisfy the visitors. Meanwhile, the villagers are the main actors on the tourist village industry. They offer hospitality, local values and wisdoms to the visitors during unforgettable moment on the village. The key success factor is the readiness of the villagers to be involved on the tourist village industry. The local government supports the ministry of tourism program with the tourist village decree. Meanwhile tourism care takers (POKDARWIS) managed the tourist villages as one of the business unit of the village enterprise. The major share of the village enterprise owned by the village government. Thus the village government invested some amount of money from the village budget. When the business is growing, the Pokdarwis enjoys some profit and re-allocate the profit for re-investment on the tourist village attractions, amenities and contribute some profit to the village government.

Another program to support tourist village industry from the ministry of tourism is called a home stay program. The purpose of the program is to invite the tourists who like to spend couple days on the village while enjoying socioculture life and values. This might attract the tourists in term of experiencing to be a villager with different theme. On the other side the villagers have opportunities to earn money from providing the home stay at their house. The villagers might build the new home stay for the tourists on their land or they provide one separated room for the home stay purpose. The villagers might cook the local dishes and the tourists learn how to cook. This might create another opportunities for a cooking class. Experiencing the cooking class on the middle of the rice field is another service which is offered to the tourists. Experiencing to be like farmer, fisherman, and other profession on the village could be another tourist's packages. Thus most elements on the village involve on the tourist village industry and create multiplier effects. The villagers are the main actors who enjoy the tourist village cash flow and other benefits. The tourist village industry should be integrated to the mega project Mandalika as buffering village to support the Mandalika project.

The central government has a great concern to develop tourism beyond Bali. The purpose is to create the new regional economic growth similarly to the concept creating "the New Bali". Lombok is located next to Bali, therefore, the mega project of Mandalika was established in Lombok. It is also called the special economic zone "Mandalika". It was elected to be the special economic zone since it has factor conditions. The beautiful panorama with clean beach water and the white oval sand surrounded with the beautiful green hill makes it perfect to be the tourist center in Lombok. However, lack infrastructure on the tourist destination affects minimum number of visitors. The central government have invested much money for better infrastructure to the Mandalika accessibilities, airport 
railway, and others to attract investors from many different countries. Many hotel investors have been working on the project site with many suppliers to pursue project deadline. Competition with hotel industry will absorb the local labors and train them to produce the better service. This makes another business appears on the regions and produce multiplier effect with their business ecosystem. Another investment to support the Mandalika project is a Moto GP industry. Moto GP arena project has been starting since 2018 to complement the mega project "Mandalika" to boost the domestic and international visitors. The French investor initiated the moto GP arena project located on the mega project Mandalika. This will create another business ecosystem and opportunities. The Lombok tourist village industry should play their role to support the tourism ecosystem for its competitiveness

\section{The Setanggor tourist village industrial cluster}

The Setanggor tourist village is located in central Lombok. It is about 20 kilometers away from the capital city of West Nusa Tenggara Province. The village is very closed to the airport approximately 10 minutes riding motor bike and about 15 kilometers to the Mandalika tourism zone. It is eassy to access the village with better road infrastructures. Universities and other higher education institutions such as POLTEKPAR (Politeknik Negeri Pariwisata) "the biggest tourism academy managed by the ministry of tourism" and STP (Sekolah Tinggi Pariwisata) Mataram "the Mataram tourism academy" might support the Setanggor tourist village industry development. Meanwhile, University of Mataram supported the village through research activities and allocating KKN (kuliah kerja nyata) program referring to student's community service. The group of students from many different diciplines applied their knowledge to support the village. The Setanggor tourist village propose the halal tourist village industry concept. The village provide the halal food and drinks. The halal concept is also applied when you decide to stay some nights in the village. It means the married couple is halal and welcome to stay and sleep together in one room while unmarried couple should be in separated room. The sexy clothes categorized non-halal customs so that they should be covered by the tenun craft and scarf made in Setanggor village.

The history of the Setanggor tourist village explained by our interviewee "Initiator of the Setanggor tourist village":

"I saw the Setanggor village has many potentials such as art and culture, local wisdom, and beautiful nature in 2016. I was a chair of the Indonesia Islamic tourism for the halal tourist village association in west Nusa Tenggara province. We got the program of sharing basic needs on Friday to the poor. We came door to door to Setanggor villagers and surrounding. We were quite familiar to the villagers and saw the village potential to be the tourist village. Thus, we initiated the meeting about how Setanggor transforms to be the tourist village and its benefit with religious leaders, youth, and Setanggor's stakeholders. Most villagers agreed to transform the Setanggor village to be the tourist's village. What do we do?"
Issues related to be the tourist village are varying. Most villagers were agreeing while some others disagree. According to the board of tourist promotion agency of central Lombok:

"There were so many complains to be the tourist village for the first time. Most villagers thought many tourists carry drugs and narcotics and drink alcohol. Meanwhile, the sexy dressed will affect the youth and it will affect our own culture by generations. The explanation of the importance "awik-awik" or (informal laws agreed by the villagers) is part of the solution. Therefore, the concept of the Halal tourist village was given in Setanggor village. Further Lombok has been known to be the world best halal tourism".

Based on the information above it might conclude that the halal tourist village concept was proposed to capture the moeslem market from middle east countries. It was quite relevant where Lombok was inaugurated as the winner of halal tourism in the world in Abu Dhabi, 2016. The village stakeholders and villagers are the most important aspect to be involved. Communication among stakeholders matters a lot for building halal tourist village industry on the Setanggor village. Informal approach with sharing basic needs to the poor is a key success factor of having good communication with the village stakeholders. Thus design program for tourist packages can be discussed and executed. Further explanation about the concept and products offered on the Setanggor village were also told by the informant on April 2019:

"Halal tourism means excellent service. We need to train the villagers for welcome smile to the tourists and show them its part of the traditions. If the international tourists come to the village, we welcome them with the tenun crafts made in Setanggor. They will be covered modestly to follow the standard operating procedures of the Halal tourist village industry. We explained to the international tourists this is a culture to wear sarung and they become happier. Thus, the halal tourist village launched in May 2016."

Another key success factor of implementing the Setanggor tourist village industry is consistently promoting the halal tourist village concept which is agreed among stakeholders and villagers. Meanwhile explaining the concept of halal to the international tourists and the logic reasons behind the activities in the village is very crucial to satisfy the tourists. The integrated activities of providing the sarung made in Setanggor to the ceremonial welcome which benefiting the villagers who offer related product and services are valuable ideas to the villagers. They earned the money from the activities and enjoy the profit. It was told by the interviewee:

"The Lombok international airport is very closed to the Setanggor village for about 10 minutes drive with good accessibility. It is a plus point where tourists might come 
to the village and enjoy tourist package offered. Previously, the Setanggor craft products support the Sukarara (Tenun craft industrial cluster). It is abit confusing at the beginning because they thought the tourist village industry is typical beautiful village, with less confidence, nothing beautiful here to be the tourist village. Having focus group discussion about the tourist village concept, they become open-minded. Tourist village industry is about the art and culture heritage, local values and wisdoms, hospitality which make them unique. The Setanggor village have the success story to be the champion of the art, drama, and gamelan where very young generations (5 to 10 years old) represent West Nusa Tenggara province for the art-performing at Jakarta"

Information above help us to understand the importance of the location and how infrastructure and accessibility support the success story of developing tourist village industry. Shifting from the common platform of supplying the tenun craft to Sukarara to be direct seller is another part of innovation activities. Thus, they are also performing tenun processing activities where tourists might learn directly from the tenun makers. On the other side, changing paradigm of the halal tourist village concept need technical supports from many stakeholders. Gradually they would be open-minded and find the path where to go. In order to manage the tourist village industry, the POKDARWIS (tourism caretakers) members were elected from the native Setanggor villagers. The elected chairman of POKDARWIS explained us about the Pokdarwis in detail.

"The POKDARWIS Sekarteja Mertakmi was established in June 2016. We propose the concept of Halal tourist village based on the agreement with stakeholders. The concept is free alcoholic drinks and use sarung made in Setanggor village to enjoy the attractions offered on the village. We use awik-awik (informal tradition laws) to regulate standard operational procedure. There are about 38 members and we recruit head of sub-village where two of them reject to participate. Pokdarwis was supported by 14 local guide in the village. They were trained for upgrading English skills by PT ITDC (Indonesia Tourism Development Centre) who managed the mega project Mandalika to run the tourist village program. There are about 14 tourist packages which is potential to be the tourists packages: a) Cassava garden offers harvesting cassava and grill them alone with the Setanggor black coffee on the middle of cassava garden. b) Agro tourism offers harvesting seasonal fruit such as the dragon fruit, melon, pineapple on the garden. c) artculture lesson offers tourist to learn art, gendang belek and gamelan music instruments in art-house supported by PT ASDP (the national state enterprise) with the total of $\mathrm{Rp} \mathrm{350,000,000.} \mathrm{d)} \mathrm{Ritual} \mathrm{tourism} \mathrm{offers} \mathrm{Raden}$ Kekah cemetery who spread Islam beliefs for the first time in Lombok. We should climb upstair for about 999 stairs supported by ministry of village". e) Grow and harvest rice on the rice field. f) Lunch on the middle of rice field. g) Recite and study al-quran on the middle of rice field. h) life of Islamic boarding school (pesantren), i)ngendeng api j) jambek and mereweh, etc"

Based on the information, Pokdarwis had external networking and participation with many different institutions. They supported pokdarwis in term of capacity building, English skills, and other skills to manage the tourist village. Other institutions also participated to support the pokdarwis with facilities and infrastructure needed to accelerate the village. Their products and services are produced from the native local daily life of the Setanggor village with many different activities to many different tourist packages. There is no intellectual properties produced based on the activities but they got strong knowledge and assistance from ministry consultants.

The informant also explained the developmet of the Setanggor tourist village industry as follows.

"The Setanggor village enterprise have some diversified business. There are 2 unit homestay supported by the ministry of village in 2018, tent and party equipment rental, water drink business, art shop, and cooperative. There are about 41 house unit offered by the villagers to be the homestay. If the villagers have the house with three rooms, two of them used for the family and another one room offered to be homestay. The Setanggor tourist village have the total of 82 house units to be offered with 104 rooms in 2018. Most of the Setanggor village guests were the International tourists from Russia, China, French, Sweden. Most of the guests were international guests who obtained marketing information from social media such as instagram, facebook and online travel agents such as booking.com, travel loka, RB \& B. Collaboration with domestic and international travel agents from French and Hongkong were also another key success factor while the online travel agent and social media were the greatest contributors for the international visitors coming to the Setanggor village. Domestic and international universities and higher education institutions came to the village to support technical skill and study community based tourism in the Setanggor village such as university of Mataram, Kyoto university, Glasgow university, STP Bali, POLTEKPAR Lombok, STP Mataram".

\section{The Mertak tourist village industrial cluster}

Mertak village is located in rural area but near to the mega project of the Mandalika tourism zone. The initial step of community-based tourism in the Mertak village has been known as the Gunung Tunak eco-tourism but it does not work optimal. The historical project started when the korea forest service signed momerandum of understanding (MOU) with the ministry of forest Republic Indonesia to promote international eco tourism trend in October $12^{\text {th }}, 2013$. The purpose of the MOU is to develop ecological protection and landscape for sustainable eco tourism. Secondly, promote community based eco-tourism beside Bali. Thirdly, sharing strategy related to eco-tourism management applied in the South Korea. 
As one of the interviewee supplemented:

There are some countries in the world receive the grant to assist the community empowerment relate to the forest development. The grant will be allocated based on the community-based tourism. The development concept of the forest should involve communities surrounding the forest project. Based on the data and criteria set by the Korean government, Mertak village was chosen to meet the criteria. The MOU conclude two aspects of cooperation: upgrade human resource capacity of the local communities, the central and local government officers, and technical service unit officer and infrastructure development.

\section{Forming group}

The second step of the Mertak tourist village development is called forming group and capacity building. Managing the project of the Mertak tourist village industry in Gunung Tunak is a POKDARWIS (tourism care takers) concerned. There were about 88 members of Pokdarwis Tunak besopok to manage the Gunung Tunak project.

As one interviewee indicated:

The pokdarwis members have been divided into some divisions: guide, handicraft, culinary, and butterflies. Corporate social responsibility programs have been allocated for $5 \%$ from the gross sales to buy sarung. There is a social agenda to support the villagers. Many parties involve supporting the gunung tunak eco-tourism. They are tenun crafter, farmers, fisherman, stall shopper, schools, home stay.

As one informant noted:

The most important point to build tourist village is building community characters. On this stage, we should not think of money but how we ask communities to build a long process of building good characters. However, the villagers feel lack confidence to sell the tourist packages: hiking or soft tracking, biking, tourist sub-village.

This information explained most of the pokdarwis members and villagers have lack confidence with the tourist village products offered. Therefore, some other communities reject the new status of the village because of the cultural values consideration. Thus, awik-awik is used to solve the problems on the village.

TABLE I. HISTORY TUNAQ BESOPOK (FORMING GROUP)

\begin{tabular}{|c|l|}
\hline Year & Activities \\
\hline 2013 & Personal approach and share perception of forming group \\
\hline $2013-2015$ & $\begin{array}{l}\text { Initiate group, group approach, share vision, group } \\
\text { assistance }\end{array}$ \\
\hline 2016 & Forming group, reguler meeting, assistance \\
\hline $2015-2020$ & Achievements and reports \\
\hline $2018-2020$ & Tourist packages development \\
\hline
\end{tabular}

(Source: BKSDA, 2020)

\section{Tunak besopoq capacity building}

Capacity building have been done into three batch. The first batch of the capacity building is the first ecotourism management in 2015 followed by 25 people and held in South Korea. The second batch followed by 31 people in
2015 with the theme of butterfly's conservation, handicraft and tenun hand waving in Lombok. The third batch followed by 16 people held in Korea. Number of training activities for the group of tunak besopoq were 16 trainings involved 312 people until December 2019.

TABLE II. TRAINING ACTIVITIES

\begin{tabular}{|c|c|}
\hline Year & Completed Training \\
\hline 2015 & $\begin{array}{l}\text { - Eco tourism management (South Korea) } \\
\text { - Handicraft trainings }\end{array}$ \\
\hline 2015 & $\begin{array}{l}\text { - Butterflies conservation } \\
\text { - Guiding technique }\end{array}$ \\
\hline 2016 & $\begin{array}{l}\text { - General and leadership training } \\
\text { - Eco-tourism management }\end{array}$ \\
\hline 2017 & $\begin{array}{l}\text { - Handicraft training } \\
\text { - Cullinary training } \\
\text { - Butterflies }\end{array}$ \\
\hline 2017 & $\begin{array}{l}\text { - Interpretation skills } \\
\text { - Ecotourism management (South Korea) }\end{array}$ \\
\hline 2018 & $\begin{array}{l}\text { - Internship guiding and language skills } \\
\text { - Bench marking (Gili asahan eco lodge) }\end{array}$ \\
\hline 2019 & $\begin{array}{l}\text { - Hospitality, restaurant and hotel management, chiropraxi } \\
\text { training } \\
\text { - Asset management }\end{array}$ \\
\hline
\end{tabular}

\section{Strengthening institution capacity}

Strengthening institution capacity could be done into some ways. Firstly, technical assistance was given to the group every two weeks. Secondly, Discussion about training needs with local communities. Finally guiding the tourists to enjoy the gunung tunak ecotourism.

Facilities and infrastructure development

TABLE III. FACILITIES AND INFRASTRUCTURE DEVELOPMENT

\begin{tabular}{|c|c|c|c|c|}
\hline No. & Facilities & Duration & Budget & Implementor \\
\hline 1 & $\begin{array}{l}\text { Connecting Street } \\
\text { to the gate } 370 \\
\text { meters and } 10 \\
\text { meters wide }\end{array}$ & 2016 & $\begin{array}{l}\text { BKSDA } \\
\text { NTB } \\
\text { (technical } \\
\text { unit) }\end{array}$ & $\begin{array}{c}\text { Public works, } \\
\text { central } \\
\text { lombok }\end{array}$ \\
\hline 2 & $\begin{array}{l}\text { Water networks } \\
\text { from perempung } \\
\text { to the gate } 1900 \\
\text { M }\end{array}$ & 2016 & $\begin{array}{l}\text { BKSDA } \\
\text { NTB } \\
\text { (technical } \\
\text { unit) }\end{array}$ & $\begin{array}{c}\text { BKSDA NTB } \\
\text { (technical } \\
\text { unit) }\end{array}$ \\
\hline 3 & $\begin{array}{l}\text { Building water } \\
\text { pool }\end{array}$ & 2016 & $\begin{array}{l}\text { BKSDA } \\
\text { NTB } \\
\text { (technical } \\
\text { unit) }\end{array}$ & $\begin{array}{l}\text { BKSDA NTB } \\
\text { (technical } \\
\text { unit) }\end{array}$ \\
\hline 4 & $\begin{array}{l}\text { Beringin tree } \\
\text { seedling @2,000 } \\
\text { trees }\end{array}$ & 2016 & $\begin{array}{l}\text { BKSDA } \\
\text { NTB } \\
\text { (technical } \\
\text { unit) }\end{array}$ & $\begin{array}{c}\text { BKSDA NTB } \\
\text { (technical } \\
\text { unit) }\end{array}$ \\
\hline 5 & $\begin{array}{l}\text { Build ing } \\
\text { information center }\end{array}$ & $\begin{array}{c}2016- \\
\text { completed }\end{array}$ & $\begin{array}{c}\text { Korea forest } \\
\text { service }\end{array}$ & $\begin{array}{c}\text { KFS \&PT } \\
\text { KIFC }\end{array}$ \\
\hline 6 & $\begin{array}{l}\text { Building multi } \\
\text { function } \\
\text { auditorium }\end{array}$ & $\begin{array}{c}2016- \\
\text { completed }\end{array}$ & $\begin{array}{l}\text { Korea forest } \\
\text { service }\end{array}$ & $\begin{array}{c}\text { KFS \&PT } \\
\text { KIFC }\end{array}$ \\
\hline 7 & Parking area & $\begin{array}{c}2016- \\
\text { completed }\end{array}$ & $\begin{array}{c}\text { Korea forest } \\
\text { service }\end{array}$ & $\begin{array}{c}\text { KFS \&PT } \\
\text { KIFC }\end{array}$ \\
\hline 8 & Ground breaking & $\begin{array}{l}\text { November, } \\
2016\end{array}$ & & \\
\hline 9 & $\begin{array}{l}\text { Visitor center, } \\
\text { multi function } \\
\text { building, butterfly } \\
\text { center, camping } \\
\text { ground, trail track }\end{array}$ & $2016-2017$ & KFS & PT. Tae Sung \\
\hline 10 & $\begin{array}{l}\text { Enrichment } \\
\text { building and } \\
\text { maintainance }\end{array}$ & 2018 & KIFC & KIFC \\
\hline
\end{tabular}

(Source: BKSDA, 2020) 
KFS for Korean forest service KIFC for PT Korea Indonesia Forest Cooperation.

TABLE IV. SERVICE PRODUCTS

\begin{tabular}{|c|l|}
\hline No. & Service Products \\
\hline $\mathbf{1}$ & Camping ground: camping, camp fire, soft treckking, sailing \\
\hline $\mathbf{2}$ & Mountain cycling: explore the untouchable tunak forest \\
\hline $\mathbf{3}$ & Bird watching \\
\hline $\mathbf{4}$ & Cliff jumping \\
\hline $\mathbf{5}$ & Deer feed \& Butterflies identification \\
\hline $\mathbf{6}$ & Wellness and leisure \\
\hline
\end{tabular}

(Source: BKSDA, 2020)

\section{The Pijot tourist village industry cluster}

Pijot village is located in rural village at east Lombok where $60 \%$ of the area is a coastal area. Most population works to be the fishermen and related coastal works. Eco tourist village industry development started in 2019. They found high poverty level along the coastal area and tourism industry is part of the alternative solution. The first survey of the Pijot potential took place in 2019 with the Pijot head village. After the survey, Muara Selayar was chosen for the pilot project of the Pijot tourist village. Thus two groups of the student community service with different theme came and started the project to develop Muara Selayar project. The first team is a zero-waste team and the other team is a tourism. The students have their own programs to develop the region. They grew bakau trees along the Muara Selayar so that the fish ecosystem is getting better. When the student community service team finished their programs and continuous works done by the researcher team. Personal approach to the youth group had been done and introduced them about the concept of the Pijot tourist village industry with the pilot project in Muara Selayar point. Reguler discussion about the Pijot tourist village industry took place in Muara Selayar. Pokdarwis was found in September 2020 to manage the Pijot tourist village industry. They create tourism attractions for bamboo rafting in Muara Selayar. The knowledge of assembling the boat is very useful for bamboo rafting attractions. The water cycling is another tourism attraction in Muara Selayar. While camping ground is other optional attractions. Thus, soft launching of the Pijot tourist village industry took place in September $20^{\text {th }}$, 2020.

Community service team used a national competitive funding of community service prongrams for tourist development. Using University of Mataram networks, the local governmet paid attention on the soft launching. Secretary of department of tourism West Nusa tenggara Province came to the launching and gave a speech. Head of tourism department East Lombok regency came and gave a speech. Other guests from industry came to support the Pijot tourist village industry. PT Gudang Garam, PT Selaparang energy supported the launching with their CSR programs. Local media and electronic media also involved in promoting the tourist village. The launching was successful and the pilot project of Muara Selayar was noticed by the domestic toueists since the target market is a local and domestic market especially the next village population and the pijot local tourist population.

\section{B. Discussion}

The Lombok tourist villages have implemented open innovation activities to some degrees. The Setanggor tourist village and Gunung tunak ecotourism are the most active of open innovation activities. This might happen because they operated before the pandemic covid 19 when tourism industry was growing. On the other hand, the Pijot tourist village industry performed the least active open innovation activities since it was launched during pandemic covid 19 on september 20, 2020. The three villages have been developed by the government-university-industry-community-media partnership. Collaboration among these institutions supports open innovation activities. The government plays the most significant role to the tourist village development. Thus, government supported facilities and infrastructure to support the three tourist villages. The budget allocations relevant to the tourist village development have been spent for homestay program. Thus, the government have engaged other institutions to support the tourist village industry such as the state-owned enterprises, other domestic and international foundations, universities or other higher institutions, and international partners. These companies and institutions will support the villages from many different aspects. Further, Korean forest service and university of Mataram are the most successful intermediaries for Gunung Tunak ecotourism and Pijot tourist village industry cluster.

Based on the information above, open innovation activities could be analyzed as mentioned in Table $\mathrm{V}$.

TABLE V. OPEN INNOVATION IN THE TOURIST VILLAGE INDUSTRY

\begin{tabular}{|c|c|c|c|}
\hline $\begin{array}{c}\text { Open } \\
\text { Innovation }\end{array}$ & $\begin{array}{c}\text { Setanggor } \\
\text { Village }\end{array}$ & Mertak Village & Pijot Village \\
\hline \multicolumn{4}{|c|}{ Inbound Open Innovation } \\
\hline $\begin{array}{l}\text { Customer } \\
\text { Involvement }\end{array}$ & $\begin{array}{l}\text { High customer } \\
\text { involvement }\end{array}$ & $\begin{array}{l}\text { High customer } \\
\text { involvement }\end{array}$ & $\begin{array}{l}\text { High customer } \\
\text { involvement }\end{array}$ \\
\hline $\begin{array}{l}\text { External } \\
\text { Networking }\end{array}$ & $\begin{array}{l}\text { Social media, } \\
\text { facebook, } \\
\text { instagram, ITX, } \\
\text { OTA, Poltekpar, } \\
\text { STP, domestic } \\
\text { and international } \\
\text { tour operator, } \\
\text { magazine, } \\
\text { newspaper, } \\
\text { electronic media }\end{array}$ & $\begin{array}{l}\text { Facebook, } \\
\text { instagram, other } \\
\text { social media, } \\
\text { University of } \\
\text { Mataram, PT } \\
\text { Pertamina, } \\
\text { BKSDA, } \\
\text { ITX,OTA, } \\
\text { Korean } \\
\text { government \& } \\
\text { companies }\end{array}$ & $\begin{array}{l}\text { University of } \\
\text { Mataram, local } \\
\text { government, } \\
\text { PT energi } \\
\text { selaparang, } \\
\text { facebook, } \\
\text { instagram, } \\
\text { local } \\
\text { newspaper, } \\
\text { local TV }\end{array}$ \\
\hline $\begin{array}{l}\text { External } \\
\text { Participation }\end{array}$ & $\begin{array}{l}\text { High } \\
\text { participation- PT } \\
\text { Angkasa Pura, PT } \\
\text { ASDP, Ministry } \\
\text { of tourism, } \\
\text { ministry of village } \\
\text { development, } \\
\text { ministry of public } \\
\text { works and public } \\
\text { housing }\end{array}$ & $\begin{array}{l}\text { High } \\
\text { participation- } \\
\text { The korean } \\
\text { forest ministry, } \\
\text { PT pertamina, } \\
\text { PT } \\
\text { Baliminatama, } \\
\text { PT Dinanda, PT } \\
\text { Tabitha, PT } \\
\text { Karya Pratama }\end{array}$ & $\begin{array}{l}\text { Low } \\
\text { participation- } \\
\text { University of } \\
\text { Mataram, } \\
\text { Ministry of } \\
\text { research and } \\
\text { technology, } \\
\text { local } \\
\text { government, } \\
\text { PT Gudang } \\
\text { garam, } \\
\text { Antangin, } \\
\text { freshcare }\end{array}$ \\
\hline $\begin{array}{l}\text { Outsourcing } \\
\text { R\&D }\end{array}$ & $\begin{array}{l}\text { Consultants of } \\
\text { some ministries }\end{array}$ & $\begin{array}{l}\text { Korean } \\
\text { government }\end{array}$ & $\begin{array}{l}\text { University of } \\
\text { Mataram }\end{array}$ \\
\hline $\begin{array}{l}\text { Inward IP } \\
\text { licensing }\end{array}$ & None & None & None \\
\hline \multicolumn{4}{|c|}{ Outbound open innovation } \\
\hline Venturing & Local government & $\begin{array}{l}\text { Korean } \\
\text { government }\end{array}$ & $\begin{array}{l}\text { University of } \\
\text { Mataram, }\end{array}$ \\
\hline
\end{tabular}




\begin{tabular}{|l|l|l|l|} 
& & & $\begin{array}{l}\text { Ministry of } \\
\text { research and } \\
\text { technology }\end{array}$ \\
\hline $\begin{array}{l}\text { Outward IP } \\
\text { licensing }\end{array}$ & None & None & None \\
\hline $\begin{array}{l}\text { Employee } \\
\text { involvement }\end{array}$ & High & High & High \\
\hline
\end{tabular}

(Source: Data proceed, 2020)

Based on the table above, there are so many institutions involve on the cluster development. Therefore, open innovation activities on the Lombok tourism village industrial cluster could be seen on the figure below

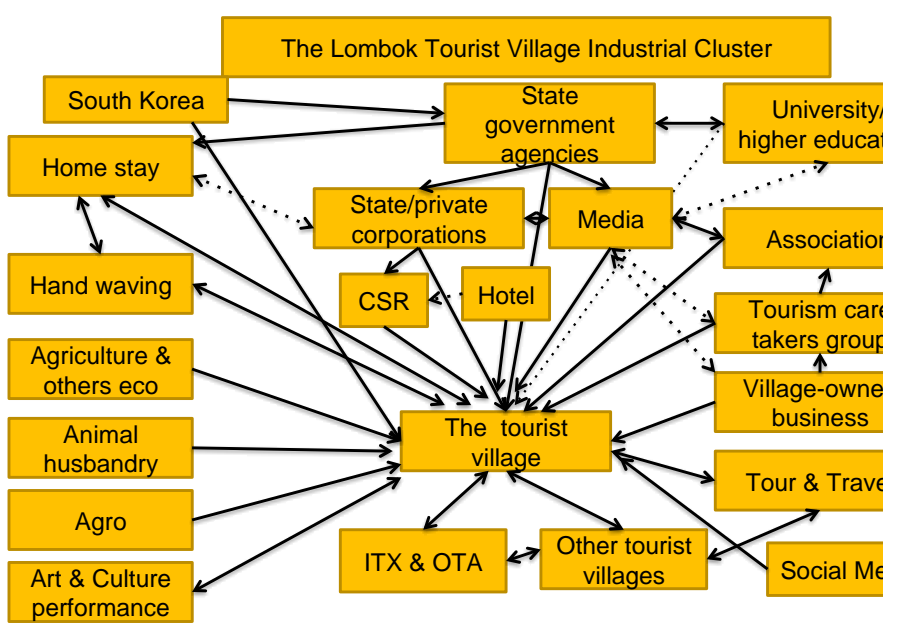

FIG. 1. The Lombok tourist village industrial cluster

\section{IV.CONCLUSION}

This research try to explain in what extent the Lombok tourist village industrial cluster has engaged open innovation activities. Inbound open innovation is much more dynamic than outbound open innovation. Inbound open innovation is the greatest contributor. External networking and participation are the most dynamics than others. On the other hand, outward intellectual property licensing and inward intellectual property licensing are none on the cluster. Meanwhile outbound open innovation has been applied on the tourist villages. Venturing and employee involvement were also dominant on the tourist village industry development. Open innovation activities on the Lombok tourist village industrial cluster could be identified from new types of relationship on the cluster as seen on the figure 1. This study has some theoretical contributions derived from exploratory case study of open innovation practices into three tourist villages. This study builds on the prior study developed. This study confirmed open innovation practices also occurred in small-and-mediumsized enterprises using cluster approach mentioned by Porter [23]. This study filled the gap that open innovation practices has been researched on the multinational corporations and it rarely found in small-and medium-sized enterprises

The above finding emphasized the importance of community readiness to accept the tourism industry. The village stakeholders are the main key to campaign the concept of the tourist village industry. Sharing vision with the village stakeholders would generate similar perceptions to run the successful tourist village industry programs and packages. Thus, some barriers to success could be eliminated with awik-awik

Since it was mentioned in the master plan of the tourism industry located in Bali, NTB, NTT, therefore, the multiple case study should represent the three provinces. However, this study focused on the multiple case studies of the Lombok tourist village industry. Multiple case studies based on the coverage area have become the limitation on the research. Based on the research finding, open innovation activities could be explained based on the inter-relationship among institutions on fig 1 . The study of networking among institution and knowledge sharing model are very potential for the future research.

\section{REFERENCE}

1] Chesbrough, H. 2003a. open innovation: the new imperative from creating and profiting from technology. Boston, USA: Harvrd Business School Publishing. 227 p. ISBN 978-1-4221-0283-1

[2] Chesbrough, H. 2003b. The Era of Open Innovation. MIT Sloan Management Review. Vol. 44:3 p.35-41 ISSN 1532-9194

[3] Dahlander, Linus, and David M. Gann. "How open is innovation?." Research policy 39.6 (2010): 699-709.

[4] Chesbrough, H. 2004. Managing open innovation: chess and poker. Research Technology Management vol. 47:1 P.23-26. ISSN 08956308

[5] Lichtenthaler, U.2008. Open innovation in practice: An Analysis of Strategic Approaches to Technology Transaction. IEEE Transactions on Engineering Management. Vol. 55:1. P. 148-157. ISSN 0018-9391

[6] Bianchi, L., et al. "Young stellar populations in the local group: an HST and GALEX comprehensive study." Astrophysics and Space Science 335.1. 2011: 249-255.

[7] Vande Vrande, V. \& de Jong, J. \& Vanhaverbeke, W. \& de Rochemont, M. 2009. Open Innovation in SME: Trends, motives and Manageent Challenges. Technovation. Vol 29(6-7). P. 423-437 ISSN 0166-4972

[8] Hotz-Hart, Beat. Innovation Schweiz: Herausforderung für Wirtschaft und Politik. Rüegger, 2003.

[9] Davis, Mark E., et al. "Evidence of RNAi in humans from systemically administered siRNA via targeted nanoparticles." Nature 464.7291. 2010): 1067-1070.

[10] Lee, Won-Jae, and J. A. Lucey. "Formation and physical properties of yogurt." Asian-Australasian Journal of Animal Sciences 23.9. 2010: 1127-1136.

[11] Schroll, Alexander, and Andreas Mild. "A critical review of empirical research on open innovation adoption." Journal für Betriebswirtschaft 62.2. 2012: 85-118.

[12] Podmetina, Daria, and Daria Volchek. "The role of market expansion, environmental turbulence and cost-saving strategies on cooperation on innovation in Russia." International Journal of Business Innovation and Research 10.2-3. 2016: 225-245.

[13] Putri, Jayanti Kartika, and Dana Indra Sensuse. "Obstacle factor analysis of E-Government implementation at the Ministry of Tourism." 2018 International Conference on Advanced Computer Science and Information Systems (ICACSIS). IEEE, 2018.

[14] Eisenhardt, Kathleen M. "Making fast strategic decisions in highvelocity environments." Academy of Management journal 32.3 (1989): 543-576.

[15] Sui, Guangchao, et al. "Yin Yang 1 is a negative regulator of p53." Cell 117.7 (2004): 859-872.

[16] Eisenhardt, Kathleen M., and Melissa E. Graebner. "Theory building from cases: Opportunities and challenges." Academy of management journal 50.1 (2007): 25-32.

[17] Znaniecki, Florian. The method of sociology. No. HM24 Z6 1968. 1968. 
[18] Gill, Peter MW, Benny G. Johnson, and John A. Pople. "Two-electron repulsion integrals over Gaussian s functions." International journal of quantum chemistry 40.6 (1991): 745-752.

[19] Hale, Elizabeth D., Gareth J. Treharne, and George D. Kitas. "Qualitative methodologies I: Asking research questions with reflexive insight." Musculoskeletal Care 5.3 (2007): 139-147.

[20] Fillis, Ian, and Boram Lee. "Internationalisation of Korean performing arts: A case study analysis." European Journal of Marketing (2011).

[21] Donlan, C. Josh, and Chris Wilcox. "Integrating invasive mammal eradications and biodiversity offsets for fisheries bycatch: conservation opportunities and challenges for seabirds and sea turtles." Biological Invasions 10.7 (2008): 1053-1060.

[22] Huberman, A. Michael, and Matthew B. Miles. "Data management and analysis methods." (1994).

[23] Porter, M.E.; On Competition. Harvard Business Review, Harvard School Press, Pp197-287, 1998. 